\title{
RATE OF LIPID PEROXIDATION IN BRAIN AND LIVER TISSUES AND THE TOTAL ANTIOXIDANT STATUS OF BLOOD PLASMA IN DEVELOPING CHICKS
}

\author{
N. BALOGH* ${ }^{*}$ T. GAÁL, F. HuSVÉTH and P. VAJDOVICH \\ Department of Internal Medicine, Faculty of Veterinary Science, Szent István University, \\ H-1078 Budapest, István u. 2, Hungary
}

(Received June 14, 2000; accepted October 30, 2000)

\begin{abstract}
Age-related changes of tissue lipid peroxidation (LPO) of liver and brain, as well as plasma antioxidant capacity of broiler chicken cockerels were investigated. Tissue LPO was characterised by the spectrophotometric assessment of thiobarbituric acid reactive substances (TBARS). Plasma antioxidant power was evaluated by the measurement of total antioxidant status (TAS). Newly hatched broiler chicks had similar TAS value $(1.19 \mathrm{mmol} / \mathrm{l})$ as newborns of mammalian species. Significant changes $(p<0.05)$ were observed in the time course of all parameters. Tissue TBARS concentration was higher in the brain than in the liver at hatching, while the latter organ was found to have more effective antioxidant defence during embryonic life. The concentration of TBARS increased up to the 10th day in the liver but only up to the 21 st day in the brain, and the former was accompanied by an approximately 50\% decrease of plasma antioxidant capacity. This suggests that the liver plays an important role in forming the antioxidant defence mechanisms of the blood plasma in broiler chicks.
\end{abstract}

Key words: Lipid peroxidation, antioxidant status, chicken

Age-related changes of the antioxidant system have been studied in many species. Many observations were made on the embryonic development of the antioxidant system in chicks. It was established that the transport of lipids across the yolk sac membrane occurs only in the third week of incubation (Noble and Cocchi, 1990) and is accompanied by the transport of the antioxidant vitamin E (Gaál et al., 1995). The transport of vitamin A precedes this process via an active transport mechanism and reaches its maximum level in the second week of incubation when the development of the retina is going on. Antioxidant defence mechanisms may vary in the organs due to different concentrations of the major antioxidants. Concentrations of vitamin A, vitamin E, reduced glutathione (GSH) and activities of antioxidant enzymes superoxide dismutase (SOD) and glutathione peroxidase (GPX) were found to be significantly higher in the embryonic liver tissue than in the brain, whereas concentration of ascorbic acid was higher

*Corresponding author; E-mail: nbalogh@univet.hu; Fax: +36 (1) 478-4137 
in the latter organ (Gaál et al., 1995; Surai et al., 1996). Some of the antioxidant pathways in the developing chick embryo are regulated by the increasing oxygen consumption and cause GSH accumulation in the liver and higher SOD activity in the brain (Wilson et al., 1992). In newly hatched chicks the brain tissue is the most prone to spontaneous and to in vitro iron-induced lipid peroxidation (LPO), and is characterised by low GPX and catalase (CAT) activity (Surai et al., 1999). The susceptibility of the brain tissue to LPO is enhanced further by the increase of its polyunsaturated fatty acid content during embryonic development (Maldjian et al., 1996). Other investigations revealed many nutritional diseases of poultry that are connected with disturbances of the antioxidant system. The best known disorder is nutritional encephalomalacia of poultry that develops on the 7 th to 21 st day of life due to absolute or relative deficiency of vitamin $\mathrm{E}$ in the feed (Sallmann et al., 1991; Fuhrmann et al., 1996). Evidence was produced that increasing the n-3 polyunsaturated fatty acid (PUFA) content of the chicken diet elevates liver LPO and depresses plasma antioxidant capacity. These changes could be diminished by vitamin E supplementation of the diet (Husvéth et al., 2000). Other nutritional diseases such as vitamin A, selenium, monensin, and salinomycin-tiamulin toxicosis, tibial dyschondroplasia and pulmonary hypertension (ascites) syndrome are also closely connected with impaired antioxidant mechanisms or increased rate of free radical formation (Mézes et al., 1992; Enkvetchakul et al., 1993; Whitehead et al., 1994; Bottje and Wideman, 1995; Mézes et al., 1997). Ontogenetic changes in the antioxidant mechanisms have been observed in many other species, e.g. in rats, cattle and swine (Ledwożyw and Kądziołka, 1989; Carillo et al., 1992; Gunther et al., 1993; Gaál et al., 1996). These findings support the LPO theory of ageing (Harman, 1969) and underline the need for appropriate antioxidant defence in newborn animals. Recently new methods have been developed to characterise the antioxidant status of biological systems with a single parameter instead of measuring the levels of certain antioxidants separately. One of these methods is the total antioxidant status (TAS) assay that was developed by Miller et al. (1993) for the evaluation of antioxidant capacity of human plasma. The method was applied for detecting changes in the antioxidant power of chicken plasma by Gaál and Kopál (1997). The aim of this study was to use this method for assessing the antioxidant capacity of the blood plasma in growing chickens.

As few data are available on changes of the antioxidant system in newly hatched chicks, this study was carried out to evaluate LPO in the organs and the antioxidant status of the blood plasma in newly hatched chicks from the 1st to the 21 st day of life. We hypothesised that the atmospheric oxygen created a significant oxidative stress for the animals, causing measurable changes in the rate of LPO in brain and liver tissues and in the total antioxidant status of the plasma. 


\section{Materials and methods}

\section{Animals}

Twenty-one 1-day-old Ross cockerel chicks were purchased from a commercial hatchery (HE-ROSS Hatcheries Co., Ócsa, Hungary). The animals were kept together during the experimental period in battery cages with elevated floors and were fed a commercial diet ('starter diet' meeting the Hungarian and NRC recommendations for vitamin and nutritional substance content of feed) for broilers. The birds were kept in a controlled environment at 20 to $25{ }^{\circ} \mathrm{C}$ temperature. Additional heating was used during the initial 2-week period. Lighting was provided $24 \mathrm{~h}$ a day. The chicks had free access to feed and water. The experiment was approved by the Local Supervising Committee for the Use and Welfare of Experimental Animals (25-9/2000).

\section{Sample collection}

At each sampling time $(1,10$, and 21 days of life) 7 chicks were slaughtered, and brain, liver and heparinised blood samples were collected. After blood sampling plasma was separated from the blood cells by centrifugation (3000 rpm for $5 \mathrm{~min}$ ) and approximately 0.5 gram of each tissue sample was homogenised with physiological $(160 \mathrm{mmol} / \mathrm{l})$ saline solution. Prepared samples were stored at $-20{ }^{\circ} \mathrm{C}$ to await the analyses for maximum five days.

\section{Chemical analyses}

The rate of LPO was determined by the modified thiobarbituric acid reaction (Placer et al., 1966). The concentration of thiobarbituric acid reactive substances (TBARS) was calculated with the help of a calibration curve of malondialdehyde standard solution. The total antioxidant status (TAS) of plasma was measured by a commercial test kit (TAS kit, Randox Laboratories, Crumlin, UK). This assay employs the method of Miller et al. (1993). In this reaction 2, 2'-azinobis-(3ethylbenzothiazoline 6-sulphonate (ABTS) is incubated with a peroxidase (metmyoglobin) and hydrogen peroxide to produce the radical cation $\mathrm{ABTS}^{+}$. This has a relatively stabile green colour, which is measured at $600 \mathrm{~nm}$. Antioxidants in the added sample inhibit the formation of this colour production to a degree that is proportional to their concentration or activity. All reagents except the Randox TAS kit were purchased from Sigma-Aldrich Ltd. (Budapest, Hungary).

\section{Statistical analysis}

Data were analysed by means of one-way analysis of variance (ANOVA) and Student's $t$-test with the help of the STATGRAPHICS statistical software. Significance was accepted at 5\% confidence level. Results are expressed as means \pm standard error of mean (SEM). 


\section{Results}

One-way ANOVA revealed significant changes according to time in all parameters measured (Table 1).

The concentration of TBARS was almost three times higher in the brain of the newly hatched chicks than in their liver. At day 10 the TBARS level was almost twice higher in the liver than in the previous samples and there was no significant difference between the two organs. Another ten days later the brain TBARS concentration showed a marked increase while the level of this substance in the liver remained almost constant throughout the investigated period. The TAS value of the blood plasma of 10-day-old chicks was less than half of that measured in any other sample, which showed almost the same level.

Table 1

Concentration of TBARS in brain and liver tissues and TAS of the blood plasma in chicks

\begin{tabular}{|c|c|c|c|}
\hline \multirow{3}{*}{ Age in days } & \multicolumn{3}{|c|}{ Parameters } \\
\hline & \multicolumn{2}{|c|}{ TBARS, nmol/g wet tissue } & $\mathrm{TAS}, \mathrm{mmol} / 1$ \\
\hline & brain & liver & blood plasma \\
\hline 1 & $73^{\mathrm{a}} \pm 7$ & $26^{\mathrm{a}} \pm 1$ & $1.19^{\mathrm{a}} \pm 0.05$ \\
\hline 10 & $59^{a} \pm 2$ & $50^{\mathrm{b}} \pm 4$ & $0.46^{\mathrm{b}} \pm 0.04$ \\
\hline 21 & $110^{b} \pm 6$ & $46^{\mathrm{b}} \pm 3$ & $1.09^{\mathrm{a}} \pm 0.06$ \\
\hline
\end{tabular}

Note: results in the same column with different letters in superscript mean significant $(\mathrm{p}<0.05)$ differences

\section{Discussion}

In harmony with the findings of Husvéth et al. (2000), our data confirm that the TAS method can be applied for evaluating the antioxidant status of the blood plasma in chicks. TAS values of the newborn and developing chick were very similar to those (around $1 \mathrm{mmol} / \mathrm{l}$ ) measured in other species (Miller et al., 1993; Gaál and Kopál, 1997), except at day 10 when a significantly lower TAS value was found. This result suggests that the antioxidant mechanisms of plasma are temporarily exhausted at that period of development. It can be presumed that the antioxidant system is developed well enough to cope with the acute effects of changing from gas exchange across the chorioallantoic membrane to pulmonary ventilation during hatching, but later on it becomes exhausted by the increased rate of peroxide formation. The above findings are supported by the results of Mézes et al. (1997), who found low activities of CAT and GPX and high concentration of TBARS in the blood plasma of chicks of similar age. The marked post-hatch increase in liver TBARS concentration could have been caused by the increasing lipid content of the organ due to fat reabsorption from the yolk sac. 
After this process was completed and lipid transport from the liver ceased, no further increase in LPO could be observed. It seems that the liver may play a crucial role in the regulation of the antioxidant mechanisms of the plasma as well, as the increase of liver TBARS concentration was accompanied by a decreased plasma TAS value. The brain has a different antioxidant defence system compared to the liver, as the levels of the major antioxidants like vitamin E, GSH CAT and GPX are low in this organ but there is a relatively high vitamin C concentration which is thought to play an important role in antioxidant pathways of the embryonic chick brain (Surai et al., 1999). In this study we observed a marked increase of TBARS concentration in the brain from the 10th to the $21 \mathrm{st}$ day of development. Although neither the concentration nor the activity of individual antioxidants was measured in this experiment, one may speculate that these mechanisms are impaired at this developmental stage in the brain tissue. Others found increased LPO and decreased GPX activity in the brain tissue of chicks only at 35 days of age (Mézes, 1988). These results call attention to the fact that the brain has decreased antioxidant capacity around the third week of life, at which age nutritional encephalomalacia, which is thought to be the most important disease connected with impaired antioxidant status, most often occurs (Sallmann et al., 1991; Fuhrmann et al., 1996). A similar tendency was observed in the developing rat brain (i.e. increasing LPO till the third week of life) by Gunther et al. (1993).

In conclusion, it is stated that newly hatched chicks have a plasma antioxidant capacity similar to that of other species. The rate of LPO is comparatively low in the liver and high in the brain of 1-day-old broiler chicks. Increased LPO was observed in the liver tissue on the 10th day and in the brain tissue on the 21 st day of life, and the former was accompanied by a concomitant decrease of plasma antioxidant capacity.

\section{References}

Bottje, W. and Wideman, R. F. Jr. (1995): Potential role of free radicals in the pathogenesis of pulmonary hypertension syndrome. Poultry and Avian Biol. Rev. 6, 211-231.

Carrillo, M. C., Kanai, S., Sato, Y. and Kitani, K. (1992): Age-related changes in antioxidant enzyme activities are region and organ, as well as sex, selective in the rat. Mech. Ageing Dev. 65, 187-198.

Enkvetchakul, B., Bottje, W., Anthony, N., Moore, R. and Huff, W. (1993): Compromised antioxidant status associated with ascites in broilers. Poultry Sci. 72, 2272-2280.

Fuhrmann, H., Schultheis, S., Drommer, W., Kaup, F. J. and Sallmann, H. P. (1996): Zur Erfassung der Gewebs-Lipidperoxidation bei der Nutritiven Enzephalomalazie des Broilers. J. Vet. Med. A 43, 9-21.

Gaál, T. and Kopál, D. (1997): Comparative studies on total antioxidant status (TAS) in blood plasma of different animal species. Comp. Haematol. Int. 7, 179-180.

Gaál, T., Mézes, M., Noble, R. C., Dixon, J. and Speake, B. K. (1995): Development of antioxidant capacity in tissues of the chick embryo. Comp. Biochem. 112B, 711-716. 
Gaál, T., Vajdovich, P., Speake, B. K., Noble, R. C., Surai, P. F. and Mézes, M. (1996): Ageing and lipid peroxidation (in Hungarian, with English abstract). Magyar Állatorvosok Lapja 51, 165-169.

Gunther, T., Hollriegl, V. and Vormann, J. (1993): Perinatal development of iron and antioxidant defence systems. J. Trace Elem. Electrolytes Health Dis. 7, 47-52.

Harman, D. (1969): Prolongation of life, role of free radical reactions in ageing. J. Am. Geriatric Soc. 17, 721-731.

Husvéth, F., Manilla, A. H., Gaál, T., Vajdovich, P., Balogh, N., Wágner, L., Lóth, I. and Németh, K. (2000): Effects of saturated and unsaturated fats with vitamin E supplementation on the antioxidant status of broiler chicken tissues. Acta Vet. Hung. 48, 69-79.

Ledwożyw, A. and Kądziołka, A. (1989): Ontogenesis of antioxidant enzymes in pig (in Polish, with English abstract). Polskie Archiwum Weterynaryjne 29, 77-94.

Maldjian, A., Cristofori, C., Noble, R. C. and Speake, B. K. (1996): The fatty acid composition of brain phospholipids from chicken and duck embryos. Comp. Biochem. Pysiol. 115B, 153158.

Mézes, M. (1988): Changes in lipid peroxidation and activities of some antioxidant enzymes of chicken brain homogenates during early postnatal development In: Matkovics, B., Boda, D. and Kalász, H. (eds) Oxygen Free Radicals and Tissue Injury. Akadémiai Kiadó, Budapest, pp. 211-215.

Mézes, M., Sályi, G., Bánhidi, G. and Szeberényi, S. (1992): Effect of acute salinomycin-tiamulin toxicity on the lipid peroxide and antioxidant status of broiler chickens. Acta Vet. Hung. 40, 251-257.

Mézes, M., Surai, P., Sályi, G., Speake, B., Gaál, T. and Maldjian, A. (1997): Nutritional metabolic diseases of poultry and disorders of the biological antioxidant defence system. Acta Vet. Hung. 45, 349-360.

Miller, N. J., Rice-Evans, C., Davies, M. J., Gopinathan, V. and Milner, A. (1993): A novel method for measuring antioxidant capacity and its application to monitoring the antioxidant status in premature neonates. Clin. Sci. 84, 407-412.

Noble, R. C. and Cocchi, M. (1990): Lipid metabolism and the neonatal chicken. Prog. Lipid Res. 29, 107-140.

Placer, Z. A., Cushman, L. and Johnson, B. C. (1966): Estimation of product of lipid peroxidation (malonyl dialdehyde) in biochemical systems. Anal. Biochem. 16, 359-364.

Sallmann, H. P., Fuhrmann, H., Molnár, S. and Stegmanns, T. (1991): Endogenous lipid peroxidation in broiler chickens under dietary loads. Fat. Sci. Technol. 93, 457-462.

Surai, P. F., Noble, R. C. and Speake, B. K. (1996): Tissue-specific differences in antioxidant distribution and susceptibility to lipid peroxidation during development of the chick embryo. Biochim. Biophys. Acta 1304, 1-10.

Surai, P. F., Speake, B. K., Noble, R. C. and Sparks, N. H. (1999): Tissue-specific antioxidant profiles and susceptibility to lipid peroxidation of the newly hatched chick. Biol. Trace Elem. Res. 68, 63-78.

Whitehead, C., Farquharson, C., Rennie, J. S. and McCormack, H. (1994): Nutritional and cellular factors affecting tibial dyschondroplasia in broilers. Proc. Austr. Poultry Sci. Symp., Sydney. pp. 13-19.

Wilson, J. X., Lui, E. M. K. and Del-Maestro, R. F. (1992): Development profiles of antioxidant enzymes and trace metals in chick embryo. Mechanisms of Ageing and Development $\mathbf{6 5}$, $51-64$. 